\title{
Australian varieties improve pasture in long-term annual legume trials
}

Walter L. Graves $\square$ William A. Williams $\square$ Charles E. Vaughn $\square$ Craig D. Thomsen $\square$ Milton B. Jones

\section{More than 50 Australian legume varieties for rangeland have been introduced commercially since the mid-1980s, but none of them had been tested for their adaptability to California. To determine their viability, in 1990 we planted a number of these varieties at the UC Hopland Research and Extension Center, along with some that were already popular in California. We evaluated them over the course of 10 years, and in 1997 planted 16 more varieties that had been subsequently introduced. Many of the cultivars planted in 1990 persisted to cover more than $50 \%$ of the plots, while others covered a smaller portion and several disappeared completely. Our evaluation shows which of the new cultivars are likely to improve rangeland in Northern California coastal areas.}

T he UC Hopland Research and Extension Center (HREC) has a long history of rangeland seeding research. Many legume trials have been conducted at Hopland because of its central location in the Coast Range of Northern California and its commitment to evaluating practices that improve rangeland for livestock production in this region.

By the late 1980s, new Australian annual legume cultivars (varieties) were being introduced and marketed at a rapid pace for use on California annual rangelands, but they had not been systematically tested in California. HREC provided a valuable opportunity to test these annual legumes under controlled conditions on range-

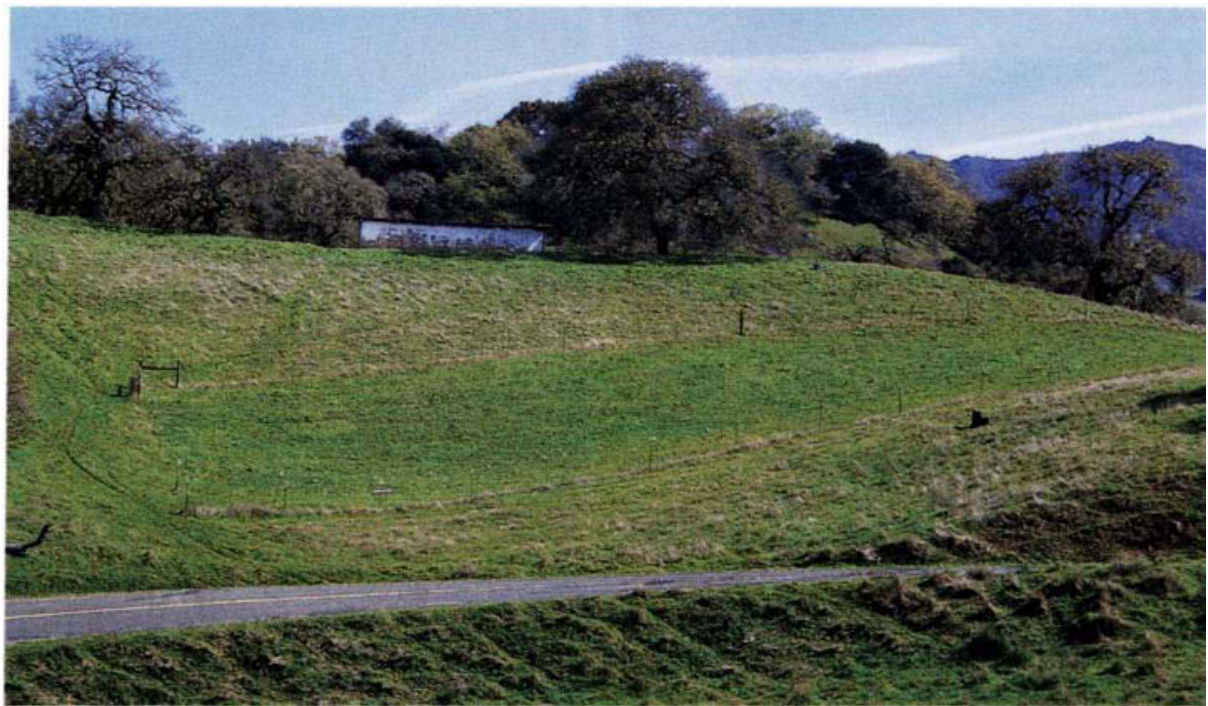

Dozens of Australian legume varieties were tested for 10 years at the UC Hopland Research and Extension Center for their suitability to the soil and climate of California's North Coast rangeland.

lands used for livestock production. In 1990, the UC Davis department of agronomy and range science and HREC staff initiated a program to evaluate these new introductions for their adaptability. Our purpose was to (1) evaluate these new Australian cultivars and compare them with the earlier commercial varieties for their long-term adaptation and persistence in this zone, and (2) provide updated recommendations for annual legume varieties in the North Coast region.

\section{New legume strains}

Annual legumes have long been used for rangeland in regions of the world with Mediterranean climates, such as Australia and California. Both rose (Trifolium hirtum) and subclovers (T. subterraneum) arrived in California in the 1930s, via Australia or directly from Mediterranean countries.

(Subclover is a type of clover that buries its pods; hence its name.) It was recognized early that these clovers were adapted to the annual rangelands of California and that they had the potential to increase livestock production by improving the quality and availability of winter, spring and early summer forage.

Except for the early release of the California-developed rose clover variety Wilton, most annual legume seeds for commercial sale have been produced in Australia. Annual legume selection and breeding programs in Australia have resulted in the availability of a wide selection of cultivars and strains. One of the major differences among subclover strains is the length of time required for the plant to flower and produce seed, which may vary by as much as 90 days. The broad selection makes it possible to find strains adapted to the range of season lengths in California's diverse rainfall and soil conditions. For example, the late-flowering subclover cultivar Mt. Barker was widely used until 1980 in areas where the average annual rainfall is greater than 25 inches.

Before the late 1970s there was a fairly high incidence of failure in establishing stands of subclover, particularly in northern coastal counties such as Mendocino and at HREC, because commercially available inoculum was not very effective under field condi- 
tions. Inoculum consists of ground peat moss used as a carrier for live Rhizubia bacteria that is appropriate for the legume type on which it is used. Properly applied, it provides the legume host with atmospheric nitrogen. However, in the 1970s, researchers from Hopland, UC Davis and a commercial inoculant company developed effective, commercially available strains of Rhizobium and a successful method of gluing high numbers of these bacteria on the seed. This clover inoculation process encouraged the use of subclovers and other annual legumes for improving North Coast rangeland.

Since the mid-1980s, more than 50 commercial cultivars of annual legumes from the Mediterranean region have been released in Australia for the improvement of rangeland. This Australian program has released cultivars for domestic use and seed export to other countries. It has been nearly 20 years since the UC Cooperative Extension updated seeding recommendations for annual legumes (George et al. 1983; Murphy et al. 1976).

\section{Seeding test plots}

We established the initial annual legume trial before the fall rains on Oct. 4,1990 , on a south-facing $15 \%$ slope of common rangeland soil at 700 feet elevation, 1 mile south of HREC headquarters. Resident plants on the site were annual grasses, forbs (broadleaved herbs), several native legumes and naturalized bur clover (Medicago polymorpha). The soil is the Sutherlin series (fine-loamy over clayey, mixed, mesic Ultic Haploxeralfs). The $\mathrm{pH}$ of the A-horizon, or topsoil layer, is 6.0. This soil is typical of many of this region in that it is deficient in nitrogen, phosphorus and sulfur. We applied single-superphosphate fertilizer $(0-20-$ $0-12)$ at the rate of 500 pounds per acre over the trial area and lightly disked the surface to prepare the seedbed for planting. We laid out the 4 -foot-by4-foot plots in a checkerboard pattern, with 4-foot borders surrounding each seeded plot. We then broadcast the 44 annual legume entries over each plot at a rate of 40 pounds per acre and replicated them three times in a ran-

TABLE 1. Percent cover (visual estimate) of annual legumes seeded in 1990 at HREC, 1991 and 2000

\begin{tabular}{|c|c|c|c|c|c|}
\hline Annual legume variety & $\begin{array}{c}\text { 3/3/1991 } \\
\text { Early spring } \\
\text { cover(\%) }\end{array}$ & $\begin{array}{c}5 / 6 / 1991 \\
\text { Late spring } \\
\text { cover(\%) }\end{array}$ & $\begin{array}{c}3 / 23 / 2000 \\
\text { Early spring } \\
\text { cover }(\%)\end{array}$ & $\begin{array}{c}4 / 24 / 2000 \\
\text { Middle spring } \\
\text { cover }(\%)\end{array}$ & $\begin{array}{c}\text { Rank in } \\
\text { persistence } \\
4 / 24 / 2000\end{array}$ \\
\hline Areces sub & 47 & 33 & 70 & 70 & 4 \\
\hline Coria-Areces sub & 11 & 20 & 43 & 47 & 18 \\
\hline CPI18358A sub & 12 & 16 & 20 & 35 & 23 \\
\hline CPI19451A sub & 17 & 23 & 43 & 37 & 22 \\
\hline CPI70094B sub & 11 & 14 & 37 & 28 & 29 \\
\hline CPI70100 sub & 19 & 27 & 37 & 33 & 26 \\
\hline Daliak sub & 16 & 1 & 50 & 27 & 30 \\
\hline Dalkeith sub & 19 & 2 & 50 & 27 & 31 \\
\hline Enfield sub & 57 & 53 & 47 & 47 & 16 \\
\hline Esperance sub & 18 & 40 & 80 & 77 & 2 \\
\hline Gaitan sub & 18 & 45 & 53 & 67 & 9 \\
\hline Geraldton sub & 30 & 1 & 57 & 33 & 24 \\
\hline Hykon rose & 27 & 40 & 30 & 70 & 6 \\
\hline Junee sub & 63 & 62 & 73 & 62 & 12 \\
\hline Karridale sub & 64 & 67 & 60 & 67 & 8 \\
\hline Koala sub & 56 & 67 & 47 & 60 & 13 \\
\hline Larisa sub & 36 & 43 & 73 & 70 & 5 \\
\hline Monte Frio rose & 28 & 52 & 33 & 63 & 11 \\
\hline Mt. Barker sub & 87 & 87 & 43 & 37 & 21 \\
\hline No. Calif mix subs & 27 & 47 & 40 & 53 & 14 \\
\hline Northam sub & 13 & 11 & 40 & 33 & 25 \\
\hline Nungarin sub & 15 & 3 & 33 & 22 & 32 \\
\hline Orellana sub & 38 & 6 & 43 & 40 & 20 \\
\hline $\mathrm{RH}-18$ rose & 20 & 48 & 23 & 33 & 27 \\
\hline Rosedale sub & 17 & 32 & 47 & 50 & 15 \\
\hline Seaton Park sub & 70 & 43 & 60 & 47 & 17 \\
\hline Span. lines subs & 36 & 22 & 30 & 30 & 28 \\
\hline T-45A sub & 13 & 32 & 57 & 63 & 10 \\
\hline Trikkala sub & 22 & 24 & 50 & 43 & 19 \\
\hline Valmoreno sub & 12 & 28 & 77 & 83 & 1 \\
\hline Wilton rose & 18 & 43 & 40 & 70 & 7 \\
\hline Woogenellup sub & 33 & 36 & 60 & 70 & 3 \\
\hline
\end{tabular}

Disappeared by 2000

Circle Valley bur medic $\quad 28 \quad 23$

Flame crimson $\quad 43 \quad 48$

Lisare cup $\quad 8 \quad 18$

$\begin{array}{lrr}\text { Paradana balansa } & 32 & 22 \\ \text { Paragosa gama medic } & 6 & 8\end{array}$

$\begin{array}{lrl}\text { Paragosa gama medic } & 6 & 8 \\ \text { Santiago bur medic } & 25 & 7\end{array}$

SCO 0172 bur medic $\quad 9 \quad 3$

SCO 9001 bur medic $\quad 13 \quad 8$

$\begin{array}{lll}\text { Seelu arrowleaf } & 26 & 48\end{array}$

$\begin{array}{lll}T-115 \text { sweetvetch } & 1 & 3\end{array}$

T-604 bur medic $\quad 16 \quad 8$

Zodiac murex medic

Within-sample date pairwise

comparisions least significant

difference for $P<.05$

domized complete block design. Each legume entry was inoculated with its host-specific Rhizobium at the rate of 5 pounds of inoculant per 100 pounds of seed.

The 44 entries consisted of 28 subclover strains (19 of T. subterraneum subspecies subterraneum, seven of $T$. $s$. subspecies brachycalycinum and two of T. s. subspecies yanninicum), four rose clovers (T. hirtum), one crimson clover ( $T$. incarnatum), one cupped clover (T. cherleri), one arrowleaf ( $T$. vesciculosum), one Balansae (T. michelianum var. balansae), five bur clovers (M. polymorpha), one murex medic (M. murex), one gama medic (M. rugosa) and one sweetvetch (Hedysarum coronarium). After broadcast-seeding these entries, we lightly raked each 
plot to cover the seed and fenced the exterior to provide some protection during seedling emergence and early growth.

Following the early spring evaluation of the trial (on March 3, 1991), 20 sheep grazed the enclosed area's seeded plots from April 8 to 12, 1991, to reduce competition from annual grasses and filaree or "pin clover" (Erodium botrys). We made a visual estimate of the percentage of establishment in each plot. We made a second late-spring visual estimate on May 6, 1991.

Subsequently, the trial site enclosure was left open for sheep to freely graze and remove summer dry residue buildup. Grazing access was continuously allowed to the trial area in subsequent years. We evaluated the trial each spring through the 1996 season.

In fall 1997, we established 16 Australian cultivars that had since become commercially available, in adjacent 4-foot-by-4-foot plots. We replicated these three times in a randomized complete block design. These 16 entries included 12 cultivars of subclover, two Persian clovers (T. resupinatum), one Balansae clover ( $T$. michelianum var. balansae) and one arrowleaf clover ( $T$. vesiculosum). Phosphorus and sulfur fertilizer was applied to all of the plots in fall 1997 and fall 1999, in the form of a triple-superphosphate and elemental sulfur mix (0-36-0-19) at a rate of 150 pounds per acre.

From the end of the 1994 season to the present, we left the trial enclosure open to continuous sheep grazing pressure of one ewe per 2 acres, as practiced at HREC. We made no attempt to protect the fall 1997 seeding from sheep grazing while the stands were emerging and establishing. We continued the visual groundcover evaluations through spring 2000. We also made visual groundcover evaluations in early and middle spring to properly evaluate early and mid- to late maturing strains. We statistically analyzed the visual groundcover estimates over the 10-year trial period for differences between strains within each evaluation date. We reported the results as a least significant difference for the $5 \%$ significance level for each sample date. We made no statistical tests to analyze between-year visual groundcover estimates on a varietyby-variety basis.

\section{Cultivar performance}

The climate at the HREC is Mediterranean with hot, dry summers and mild, rainy winters. Rainfall records for the trial period show that the longterm results of the annual legume persistence trials were not affected by unusually wet or dry periods. The 10-year average annual rainfall (measured from July 1 to June 30 ) over the trial period was 39.88 inches, slightly higher than the long-term annual rainfall for the station of 37 inches (fig. 1). Rainfall was less than average for five of the years, and the 1993-1994 season

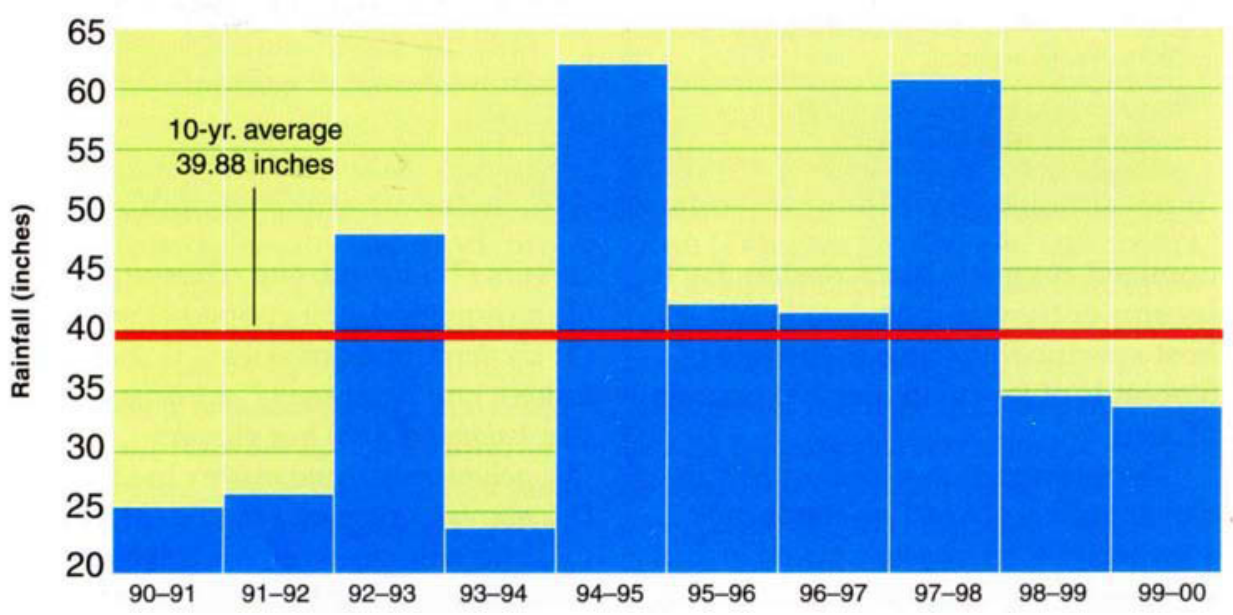

total rainfall of 23.6 inches was classified a drought year, as it was only $59 \%$ of the average rainfall for the 10-year period. Such variation is considered typical.

Early and mid-spring groundcover ratings for the 1990 seedings show when each strain has maximum cover, while the 10-year ratings provide an indication of cultivar persistence (table 1 ). Though the rainfall total for the establishment year was $69 \%$ of the longterm annual average, all of the original clover entries and most of the medics produced the flowers and mature seedpods needed to persist on this site. Only the Paragosa gama medic and T-115 sweetvetch cultivars failed to produce mature seed. Early maturing strains flowered early, produced pods and senesced earlier than other entries, requiring an earlier evaluation to assess their performance. For example, the early maturing cultivars, Daliak, Dalkeith, Geraldton and Nungarin, showed a decline in groundcover from the early to midspring. By contrast, some mid- to late maturing strains produced good early groundcover and continued to grow through the mid- to late spring, requiring a mid- to late spring groundcover evaluation to adequately document their performance (table 1).

Only the subclover and rose clovers were well adapted to this site. All of the medics, sweetvetch, cup, crimson and arrowleaf clovers began to decline as early as the 1993-1994 season, and by the 1995-1996 season had completely disappeared (table 1). This indicates that at least 4 to 6 years are needed to properly assess annual legume adaptation in this region.

As of April 24, 2000, 15 of the 44

Fig. 1. HREC annual rain-year totals (July 1-June 30 ). 
strains produced a groundcover of $50 \%$ or greater, a rating considered excellent by rangeland improvement standards. These 15 strains include both sub- and rose clover cultivars, which agree with earlier recommendations for this region. Some of the best ratings, unfortunately, were achieved by subclover strains that are not presently imported from Australia for sale in California. Many of these are experimental lines; others perform poorly in Australia, so it is not profitable to produce them because California represents such a small portion of the market. Noteworthy are the cultivars Areces, Esperance, Gaitan, Larisa, Valmoreno and an experimental strain, T-45A, from Tunisia. These strains produced only average groundcover in 1991, but improved their stands during the 10-year period. Some of the commercially available sub- and rose clovers did well, including Woogenellup subclover, Wilton rose clover and Monte Frio rose clover. Karridale subclover and Junee subclover remained constant at over $60 \%$. The old standard subclover cultivar Mt. Barker declined in groundcover during the 10-year period. All of the subspecies of the subclover genus are represented in the top $50 \%$ of strains adapted to the HREC.

Preliminary results of the 1997 seeding trial indicate that only the subclover strains improved in groundcover. The Nitro and Prolific Persian clovers, Bolta Balansae clover and Zulu arrowleaf clovers all declined in groundcover, suggesting that these strains are poorly adapted to this area and will eventually disappear from the plots (table 2).

The strains with the greatest improvements in groundcover are Denmark, Gosse and Leura subclovers. Denmark improved from $48 \%$ groundcover in 1998 to $73 \%$ in 2000 , Gosse from $38 \%$ to $73 \%$ and Leura from $40 \%$ to $73 \%$. The groundcover of Hopland J-1, Campeda, Losa, York and Riverina subclovers, also improved during this 3-year period (table 2). However, more time is needed to evaluate long-term persistence before we can make additional recommendations on these strains.

\section{North Coast pasture mixtures}

The soil and climate of the Hopland site are representative of many in the northern coastal range of California. Although UC Division of Agriculture and Natural Resources guidelines have not yet been updated, results from our research provide information that can be used in making annual legume selections for pasture improvements in the region. Based on the long-term, 10-year results and the preliminary 3-year results, we recommend that annual le-

\begin{tabular}{|c|c|c|c|c|}
\hline \multirow[b]{2}{*}{ Annual legume variety } & \multicolumn{4}{|c|}{$\begin{array}{l}\text { cover (visual estimate) of annual legumes seeded } \\
\text { in } 1997 \text { at HREC, } 1998 \text { and } 2000\end{array}$} \\
\hline & $\begin{array}{c}4 / 8 / 1998 \\
\text { Middle spring } \\
\text { cover }(\%)\end{array}$ & $\begin{array}{c}3 / 23 / 2000 \\
\text { Early spring } \\
\text { cover }(\%)\end{array}$ & $\begin{array}{l}4 / 27 / 2000 \\
\text { Middle spring } \\
\text { cover }(\%)\end{array}$ & $\begin{array}{c}4 / 27 / 2000 \\
\text { Rank in } \\
\text { persistence }\end{array}$ \\
\hline Argeles sub & 47 & 47 & 43 & 12 \\
\hline Bolta Balansae & 50 & 10 & 10 & 15 \\
\hline Campeda sub & 52 & 77 & 70 & 5 \\
\hline Denmark sub & 48 & 77 & 73 & 3 \\
\hline Gosse sub & 38 & 77 & 73 & 2 \\
\hline Goulburn sub & 53 & 57 & 50 & 10 \\
\hline GR-508 sub & 43 & 70 & 47 & 11 \\
\hline Hopland J-1 sub & 57 & 63 & 70 & 4 \\
\hline Leura sub & 40 & 63 & 73 & 1 \\
\hline Limbara sub & 43 & 63 & 63 & 7 \\
\hline Losa sub & 53 & 67 & 65 & 6 \\
\hline Nitro Persian & 38 & 27 & 12 & 14 \\
\hline Prolific Persian & 27 & 17 & 7 & 16 \\
\hline Riverina sub & 40 & 70 & 53 & 9 \\
\hline York sub & 45 & 63 & 53 & 8 \\
\hline Zulu arrowleaf & 45 & 10 & 12 & 13 \\
\hline $\begin{array}{l}\text { Within-sample date pairwise } \\
\text { comparisons least significant } \\
\text { difference for } \mathrm{P}<.05=\end{array}$ & 29.1 & 28 & 30 & \\
\hline
\end{tabular}

gume seed mixes for dryland pasture improvements in this region include the commercially available, imported subclover varieties Woogenellup, Karridale, Junee, Leura, Gosse, Denmark, Dalkeith and Losa and the rose clovers Hykon, Wilton and Monte Frio. We also suggest fertilizing at the rates used in this study. With the assistance of HREC staff and other scientists, and continued access to new varieties, we hope to continue testing and evaluating plant species for their suitability to rangeland pastures.

W.L. Graves is Advisor Emeritus, UC Cooperative Extension, San Bernardino and Riverside counties; W.A. Williams is Professor Emeritus, Department of Agronomy and Range Science, UC Davis; C.E. Vaughn is Staff Research Associate, HREC; C.D. Thomsen is Staff Research Associate, UC Davis Department of Agronomy and Range Science; and M.B. Jones is Agronomist Emeritus, UC Davis and HREC Department of Agronomy and Range Science. We acknowledge Pete Sands, for assisting with the original plantings and Bob Keiffer, who conducted a prescribed burn and helped with plot maintenance; David Dyer and his staff at the Natural Resources Conservation Service's Plant Material Center at Lockeford, Calif., for providing seed supplies of many of the experimental lines for annual legumes; Fred Thomas, who helped with the seed companies; Loshe-Mills, Clyde Robin and Kamprath, which provided seeds of many of the annual legume commercial varieties produced in south and western Australia; and Kevin Foster, deputy curator of the Australian Trifolium Genetic Resource Centre of the Western Australia Department of Agriculture, for his willingness to share many of the new and promising lines from his vast clover collection, allowing us to access these lines and cultivars early in their development and to test their performance at HREC.

\footnotetext{
References

George MR, Adams TE Jr, Clawson WJ. 1983. Seeded range plants for California. UC DANR Pub 21344, Oakland, CA. 23 p.

Murphy AH, Jones MB, Clawson JW, Street JE. 1976. Management of clovers on California annual grasslands. UC DANR Pub 2661, Oakland, CA. 9 p.
} 